\title{
Cytisus scoparius (Fam. Fabaceae) in southern Brazil - first step of an invasion process?
}

\author{
RODRIGO LEÓN CORDERO ${ }^{1,2}$, FÁBIO P. TORCHELSEN ${ }^{2}$, GERHARD E. OVERBECK ${ }^{2,3}$ and MADHUR ANAND ${ }^{1}$ \\ ${ }^{1}$ School of Environmental Sciences, University of Guelph, 50 Stone Road East, Guelph, Ontario, N1G 2W1 Canada \\ ${ }^{2}$ Programa de Pós-Graduação em Botânica, Instituto de Biociências, Universidade Federal do \\ Rio Grande do Sul, Av. Bento Gonçalves, 9500, 91501-970 Porto Alegre, RS, Brasil \\ ${ }^{3}$ Departamento de Botânica, Instituto de Biociências, Universidade Federal do Rio Grande \\ do Sul, Av. Bento Gonçalves, 9500, 91501-970 Porto Alegre, RS, Brasil
}

Manuscript received on October 8, 2014; accepted for publication on February 17, 2015

\begin{abstract}
The occurrence of Scotch broom Cytisus scoparius (L.) Link (Fabaceae), is reported for the first time in Brazil. The species has been registered in the species-rich Campos Sulinos grasslands, in the Campos de Cima da Serra, and in the Serra do Sudeste. Naturalizing populations were frequently formed in natural habitats near to human settlements, where prevailing land uses and disturbances facilitate dispersal and establishment. The plant is an invasive species that has globally caused significant damage to biodiversity and economic losses. In Brazil, the species has a strong potential for spreading into a wide range of ecosystems. The Atlantic Forest biome and part of the Pampa biome, together known as the Campos Sulinos, represent optimal areas for the species. Features of the observed populations and recommendations for management are presented.
\end{abstract}

Key words: alien species, early detection, ecology, grassland, Scotch broom.

\section{INTRODUCTION}

Scotch broom (Cytisus scoparius) is widely identified as a global pervasive species, causing extensive environmental and economic damage (Memmott et al. 1993, Sheppard et al. 2002). It has been detected in multiple countries including Chile, United States of America, India, Iran, Canada, Australia, New Zealand, and South Africa (Memmott et al. 1993, Fowler et al. 1996, Mkhize et al. 2013), and its range still is expanding (Memmott et al. 1993). There are still important gaps and country-to-country differences regarding

Correspondence to: Rodrigo León Cordero

E-mail: leoncorr@uoguelph.ca threat identification and suitable response level. Many species-rich ecosystems of South America's Southern Cone have been identified as places potentially suitable for invasion by Scotch broom in regard to general climatic conditions for the species (Potter et al. 2009). The southern part of the Atlantic Forest biome and the Campos grasslands are among the most at risk, with part of the Pampas and the Andean Patagonian biomes, also at risk but to a lesser extent (Potter et al. 2009). However, until now Scotch broom has only been cited from scattered montane localities in the Valdivian temperate forests of Chile and Argentina 
(Simberloff and Martín Nuñez 2003, Pauchard and Alaback 2004, INBIAR 2014).

South Brazilian grasslands have experienced severe habitat loss and degradation as a consequence of extensive land exploitation (Overbeck et al. 2007, Vega et al. 2009). Land use changes have been shown to be among the most important drivers of exotic plant invasions (Vitousek et al. 1997). In southern Brazil, general consensus exists regarding the environmental problems associated to the exotic invaders: tough lovegrass (Eragrostis plana), gorse (Ulex europaeus) and pine (Pinus elliotti and Pinus taeda), which cause the displacement of native flora and the modification of natural habitats. Here, we report on the first finding of Scotch broom in this region, which likely represents the first step of a new invasion process.

\section{MATERIALS AND METHODS}

\section{GEOGRAPHIC AREAS}

Our two study regions belong to the Campos Sulinos grasslands in the state of Rio Grande do Sul, southern Brazil (Overbeck et al. 2007): the highland grasslands on the South Brazilian Plateau, and the grasslands of the Serra do Sudeste, a low mountain range in the south of the state. The natural vegetation is characterized by species-rich grasslands, in mosaics with forests (Araucaria forests in the highlands, semi-deciduous forests in the Serra do Sudeste). The Campos Sulinos are subject to rapid land use changes that reduce the area of natural vegetation (Overbeck et al. 2007) and may increase vulnerability to the establishment of non-native species.

GENERAL DESCRIPTION, ECOLOGY AND INVASIVENESS OF Cytisus scoparius

Scotch broom is a shrub native to the temperate mixed and broadleaf forests of Europe (Polunin 1991), constrained by drought at the southern and cold at the northern limit of this region (Hegi 1926 in Memmott et al. 1993). Individuals may reach over $3 \mathrm{~m}$ in height, and occur, in the species' native range, in a wide variety of habitats (Srinivasan 2012). Leaves are composed of 1-3 leaflets and are deciduous, growing in alternate disposition across smooth stems (Zielke et al. 1992). Flowers are distributed on terminal axes, grouped with leaves, and have characteristic short-toothed bilabiated calices (Polunin 1991). Flowering begins in the third year, with yellow flowers that open during the months of spring, and subsequently form seedpods (Memmott et al. 1993). Seedpods range between $2.5-5 \mathrm{~cm}$ in width by $8-10 \mathrm{~cm}$ in length, and have hairs on the margins, which also help in the identification of the species (Polunin 1991). The global distribution of Scotch broom is related to European colonization around the world, to land conversion into agricultural lands and exotic tree plantations of economic value (Pauchard and Alaback 2004). A globally pervasive species and a common garden escapee (Peterson and Prasad 1998, Mkhize et al. 2013), Cytisus scoparius has been shown to cause significant declines in native biodiversity around the world (Bossard 1996, Simberloff and Martín Nuñez 2003, Shaben and Myers 2010, Srinivasan 2012). The species has negative impacts on forestry in natural forests and tree plantations, modifies the species composition at invaded sites, and hampers the establishment of rare endemic taxa, favoring generalist fauna, along with shade-tolerant and exotic flora (Zielke et al. 1992, Zarri et al. 2006, Shaben and Myers 2010, Srinivasan 2012).

FIELD WORK

The populations of Scotch Broom reported here were detected during the course of field work on the invasion by Ulex europaeus (gorse) in the region.

\section{RESULTS}

The current study has for the first time recorded the presence of naturalized Cytisus scoparius 
populations in Brazil (Table I). The species was detected in two regions of Rio Grande do Sul, Brazil's southernmost state: in the highland grasslands near São Francisco de Paula and in the grasslands of the Serra do Sudeste. In both areas, shrubs were in the early stages of development, but two spontaneous populations had already established in the southeastern region. A young stand of about 3 years old, consisting of 17 individuals (Pinheiro Machado 2), was located at approximately $2 \mathrm{~km}$ from a single mature individual occurring in a private garden in the town periphery of Pinheiro Machado. The population was growing on sandy banks of roadsides, where the frequent passage of vehicles over an unpaved track can facilitate seed dispersal (Pippa et al. 2012). The role of roadsides as biological corridors and their importance in spreading this weed is well known (Pauchard and Alaback 2004). In Herval, a well-established population grew on disturbed roadsides next to abandoned land. The specimen of São Francisco de Paula, constitutes the only record for the highland region, and occurred at $<0.5 \mathrm{~km}$ from areas heavily invaded by gorse.

This scenario sets the initial stages of habitat colonization for Scotch broom in Brazil. In the observed populations, flowering took place between October and mid-January, during Austral Hemisphere spring, which matches well with the flowering period observed in native ranges.

TABLE I

Locations across the state of Rio Grande do Sul where Scotch broom has been detected, these include gardens (Pinheiro Machado 1 and São Francisco de Paula), abandoned urban lands (Herval) and naturalized field settings (Pinheiro Machado 2). The field population of Pinheiro Machado was located at about $2 \mathrm{~km}$ from the closest neighborhood, and probably originated from a single garden individual growing in the outskirts (Pinheiro Machado 1). Height for individuals growing in gardens was estimated.

\begin{tabular}{|c|c|c|c|c|c|}
\hline Region & Locality & Latitude & Longitude & $\mathbf{N}$ & $\begin{array}{c}\text { Mean Height } \\
\text { (cm) }\end{array}$ \\
\hline $\begin{array}{l}\text { Highland grasslands } \\
\text { (Eastern Planalto) }\end{array}$ & São Francisco de Paula & $\mathrm{S} 29^{\circ} 26^{\prime} 43.98^{\prime \prime}$ & W 50³5’04.62” & 1 & 240 \\
\hline \multirow[t]{3}{*}{ Serra do Sudeste } & Herval & $\mathrm{S} 32^{\circ} 01^{\prime} 32.85^{\prime \prime}$ & W 5323'44.93”' & 9 & 260 \\
\hline & Pinheiro Machado 1 & S 31³4’39.29”' & W 5323'08.67' & 1 & 220 \\
\hline & Pinheiro Machado 2 & S 31³5’55.89”' & W 5324'16.57' & 17 & 225 \\
\hline
\end{tabular}

\section{DISCUSSION}

The early detection of first naturalized populations of invasive species can have a significant outcome for conservation (Pauchard and Alaback 2004), enabling the analysis of the behavior of the invasive species, its potential effects and, if necessary, facilitating a prompt eradication and the prevention of damage (Westbrooks 2004). Recent arrivals of alien weeds offer the chance of better understanding the processes involved in the early stages of species invasions, and in the ecological dynamics in recipient communities. This is especially important in the case of Scotch broom which is regarded as a globally noxious species. Presence of the species generally is associated to early stages of succession and to degraded areas (Zielke et al. 1992, Fowler et al. 1996, Peterson and Prasad 1998, Sheppard et al. 2002, Holst et al. 2004, Potter et al. 2009, Srinivasan et al. 2007, Srinivasan 2012).

To our knowledge, no other study has yet shown evidence of existing Scotch broom populations in South America's Atlantic shores, despite a high potentiality (Potter et al. 2009). Even though the first populations still have a limited range and, therefore, a low impact, it is known that the appearance of impacts of invasive species may lag in time, and 
not be immediately noticeable (Simberloff 2005, 2011, Goodenough 2010, Schlaepfer et al. 2011). The fact that we found the naturalized populations along roadsides can be considered quite typical for invasion processes (Parendes and Jones 2000, Christen and Matlack 2009, Mortensen et al. 2009, Pippa et al. 2012), and the importance of roadsides for invasion, has been shown for Cytisus scoparius before (Pauchard and Alaback 2004).

Given the impacts of the species in other regions of the world and the results of potential distribution modelling (Potter et al. 2009), efforts should also be made to detect further sources and foci of invasions, to monitor behavior of the species and, if necessary, to include Scotch broom into the Brazilian federal and states noxious species lists and to eradicate, where possible, the existing populations. As evidenced in other countries around the world, the eradication of the species is quite difficult once it has established, often requiring a combination of methods (e.g. biological, mechanical and chemical) (Peterson and Prasad 1998, HerreraReddy et al. 2012). Mkhize et al. (2013) described how since the 1980's infructuous attempts are still being made for eradicating Scotch broom from South Africa, as plants re-appeared a decade after initial removal, likely as a result of recolonization from the seed bank (Paynter et al. 1998). The challenge of controlling this invasive species is reinforced by the fact that no method can independently achieve completely satisfactory results. Biological control with insects is not totally effective, as Scotch broom is not seed-limited (Memmott et al. 1993), and high seed predation rates (between 70 and $99.9 \%$, in different studies) are needed, which is very difficult to achieve in most circumstances (Paynter et al. 1998, Parker 2000).

Climatic envelope modeling may constitute a suitable tool to evaluate the risk of exotic species and to project the likelihood of successful establishment (Hyvönen et al. 2012). The subtropical climate of Rio Grande do Sul produces optimal conditions for
Scotch broom invasion (Potter et al. 2009), with abundant precipitations and mild winters, that release the species from significant climatological constraints (Polunin 1991). However, generalized extrapolation to other regions should be made with caution. Given current and future trends of climate change (Potter et al. 2009), and rapid adaptability of many invasive plants (Clements and DiTommaso 2012), it is likely that present range-expansion projections fall short of a full comprehension of future scenarios. Moreover, it is highly relevant to build up sufficient knowledge on autecology of invasive species in exotic ranges, and the complex matrix of environmental and anthropogenic factors affecting them.

\section{CONCLUSIONS}

We stress the importance of early detection for invasive species of global concern like Cytisus scoparius: given the species' high capacity for dispersal (Bossard 1991), isolated escapees constitute a threat. We thus emphasize the need for strengthening surveying efforts to detect the presence of scattered populations. Early detection can have an important outcome in facilitating the management of populations at this stage, when eradication efforts also have a high likelihood of success. Special attention should be also given to the identification and preservation of vulnerable habitats. The study of early naturalizing populations can also provide important insights for, a better understanding, and subsequent prevention, of future invasion processes.

\section{ACKNOWLEDGMENTS}

The authors appreciate the help provided by the landowners of the Serra do Sudeste and São Francisco de Paula, who kindly granted us permission to access their lands. We would also like to extend our gratitude to the Fundação Grupo Boticário Proteção à Natureza, and the James S. McDonnell Foundation Complex Systems Scholar 
that supported G.E.O. and M.A., respectively. F. P. T. received a $\mathrm{PhD}$ scholarship from Coordenação de Aperfeiçoamento de Pessoal de Nível Superior (CAPES) (Brazil). Finally, we would also like to thank two anonymous reviewers whose comments improved this manuscript.

\section{RESUMO}

A ocorrência da giesta-brava Cytisus scoparius (L.) Link (Fabaceae) é citada pela primeira vez no Brasil. A espécie foi localizada em áreas com alta diversidade biológica nos Campos Sulinos, nos Campos de Cima da Serra, e na Serra do Sudeste. As populações naturalizadas são formadas frequentemente em habitats naturais, próximos a zonas povoadas, onde os diferentes usos da terra e os distúrbios facilitam a dispersão e o estabelecimento. A giesta-brava é uma espécie invasora que tem causado significativos danos à biodiversidade e perdas econômicas globalmente. No Brasil, a espécie tem um forte potencial de se propagar a um vasto conjunto de ecossistemas. O bioma Mata Atlântica e parte do bioma Pampa, conhecidos como os Campos Sulinos, representam áreas ótimas para a espécie. São apresentadas as características observadas nas populações e recomendações para o manejo.

Palavras-chave: espécies exóticas, deteç̧ão precoce, ecologia, campos, giesta-brava.

\section{REFERENCES}

BOSSARD CC. 1991. The role of habitat disturbance, seed predation and ant dispersal on establishment of the exotic shrub Cytisus scoparius in California. Am Midl Nat 126: $1-13$.

BOSSARD CC. 1996. Cytisus scoparius. In: Randall JM and Marinelli J (Eds), Invasive plants: weeds of the global garden, New York: Brooklyn Botanic Garden Publications, p. 52.

CHRISTEN DC AND MATLACK GR. 2009. The habitat and conduit functions of roads in the spread of three invasive plant species. Biol Invasions 11: 453-465.

Clements DR AND Ditommaso A. 2012. Predicting weed invasion in Canada under climate change: evaluating evolutionary potential. Can J Plant Sci 92: 1013-1020.

FOWLER SV, HARMAN HM, MEMMOTT J, PAYNTER Q, SHAW R, SHEPPARD AW AND SYRETT P. 1996. Comparing the population dynamics of broom, Cytisus scoparius, as a native plant in the United Kingdom and France and as an invasive alien weed in Australia and New Zealand. In: Moran VC and Hoffmann JH (Eds), Proceedings of the IX International Symposium on Biological Control of Weeds, Stellenbosch: University of Cape Town, p. 19-26.

GOODENOUGH AE. 2010. Are the ecological impacts of alien species misrepresented? A review of the "native good, alien bad" philosophy. Community Ecol 11: 13-21.

HERRERA-REDDY AM, CARRUTHERS RI AND MILLS NJ. 2012. Integrated management of Scotch broom (Cytisus scoparius) using biological control. Invasive Plant Sci Manag 5: 69-82.

Holst PJ, Allan CJ, CAMPBEll MH AND GILMOUR AR. 2004. Grazing of pasture weeds by goats and sheep. 2 . Scotch broom (Cytisus scoparius). Aust J Exp Agr 44: 553-557.

HYVÖNEN T, LUOTO M AND UOTILA P. 2012. Assessment of weed establishment risk in a changing European climate. Agr Food Sci 21: 348-360.

IMBIAR - INTER-AMERICAN BIODIVERSITY INFORMATION NETWORK. 2014. Invasive alien species database, I3N Argentina. Bahía Blanca: Universidad Nacional del Sur. Accesed on: 18 September 2014. [Online] URL: http:// www.inbiar.org.ar/.

Memmott J, Fowler SV, SyRETT P AND Hosking JR. 1993. What makes broom a major problem? Proceedings of the Brighton Crop Protection Conference. Farnham: British Crop Protection Council, p. 753-758.

MKHIZE VS, MHLAMBI N AND NÄNNI I. 2013. Scotch broom (Cytisus scoparius), a horticultural escapee targeted for eradication in South Africa. S Afr J Bot 86: 178-178.

MORTENSEN DA, RAUSCHERT ESJ, NORD AN AND JONES BP. 2009. Forest roads facilitate the spread of invasive plants. Invas Plant Sci Mana 2: 191-199.

Overbeck GE, Müller SC, Fidelis A, Pfadenhauer J, PILlAR VD, BLANCO C, BOLDRINI I, BOTH R AND FORNECK ED. 2007. Brazil's neglected biome: the South Brazilian Campos. Perspect Plant Ecol 9: 101-116.

PARENDES LA AND JONES JA. 2000. Role of light availability and dispersal in exotic plant invasion along roads and streams in the H.J. Andrews experimental forest, Oregon. Conserv Biol 14: 64-75.

PARKER IM. 2000. Invasion dynamics of Cytisus scoparius: a matrix model approach. Ecol Appl 10: 726-743.

PAUCHARD A AND ALABACK PB. 2004. Influence of elevation, land use, and landscape context on patterns of alien plant invasions along roadsides in protected areas of South-Central Chile. Conserv Biol 18: 238-248.

PAYNTER Q, FOWLER SV, MEMMOTT J AND SHEPPARD AW. 1998. Factors affecting the establishment of Cytisus scoparius in southern France: implications for managing both native and exotic populations. J Appl Ecol 35: 582595.

PETERSON DJ AND PRASAD R. 1998. The biology of Canadian weeds. 109. Cytisus scoparius (L.) Link. Can J Plant Sci 78: 497-504. 
PIPPA MJ, YEOH PB AND SCOTT JK. 2012. The current and future projected distribution of Solanum hoplopetalum (Solanaceae): an indigenous weed of the south-western Australian grain belt. Aust J Bot 60: 128-135.

POLUNIN O. 1991. Guía de campo de las flores de Europa, $4^{\text {th }}$ ed., Barcelona: Ediciones Omega, 796 p.

POTTER KJB, KRITICOS DJ, WATT MS AND LERICHE A. 2009. The current and future potential distribution of Cytisus scoparius: a weed of pastoral systems, natural ecosystems and plantation forestry. Weed Res 49: 271-282.

SCHLAEPFER MA, SAX DF AND OLDEN JD. 2011. The potential conservation value of non-native species. Conserv Biol 25: 428-437.

SHABEN J AND MYERS JH. 2010. Relationships between Scotch broom (Cytisus scoparius), soil nutrients, and plant diversity in the Garry oak savannah ecosystem. Plant Ecol 207: 81-91.

SHEPPARD AW, HODGE P, PAYNTER Q AND REES M. 2002. Factors affecting invasion and persistence of broom Cytisus scoparius in Australia. J Appl Ecol 39: 721-734.

SIMBERLOFF D. 2005. Non-native species do threaten the natural environment! J Agr Environ Ethic 18: 595-607.

SIMBERLOFF D. 2011. How common are invasion-induced ecosystem impacts? Biol Invasions 13: 1255-1268.

SIMBERLOFF D AND MARTíN NUÑEZ MAR. 2003. Introduced species and management of a Nothofagus/Austrocedrus forest. Environ Manage 31: 263-275.
SRINIVASAN MP. 2012. Exotic shrub invasion in a montane grassland: the role of fire as a potential restoration tool. Biol Invasions 14: 1009-1028.

SRINIVASAN MP, SHENOY K AND GLEESON SK. 2007. Population structure of Scotch broom (Cytisus scoparius) and its invasion impacts on the resident plant community in the grasslands of Nilgiris, India. Curr Sci India 93: 1108-1113.

Vega E, BAldi G, JobBÁGy EG ANd PARUelo J. 2009. Land use change patterns in the Río de la Plata grasslands: the influence of phytogeographic and political boundaries. Agr Ecosyst Environ 134: 287-292.

VITOUSEK PM, D’ANTONIO CM, LOOPE LL, REYMÁNEK M AND WESTBROOKS R. 1997. Introduced species: a significant component of human-caused global change. New Zeal J Ecol 21: 1-16.

WESTBROOKS RG. 2004. New approaches for early detection and rapid response to invasive plants in the United States. Weed Technol 18: 1468-1471.

ZARRI AA, RAHMANI AR AND BEHAN MJ. 2006. Habitat modifications by Scotch broom Cytisus scoparius invasion of grasslands of the upper Nilgiris in India. J Bombay Nat Hist Soc 103: 356-365.

Zielke K, BoAteng JO, CALdicott N AND Williams H. 1992. Broom and gorse in British Columbia: a forestry perspective problem analysis. Victoria: British Columbia Ministry of Forests, Silviculture Branch, 27 p. 